PAEDAGogia CHRISTIANA

$1 / 25$ (2010) - ISSN 1505-6872

Bogustaw Milerski

Warszawa

\title{
Aksjologia kształcenia w perspektywie pedagogiki dialogu
}

Pedagogika dialogu jest kierunkiem pedagogiki filozoficznej, który nie tylko ujmuje relację wychowawczą w kontekście dialogicznej struktury bytu ludzkiego, lecz również proponuje określoną aksjologię pedagogiczną. W odróżnieniu jednak od tradycyjnych pedagogik normatywnych, wywodzących uznawane wartości z leżących u ich podstaw etyk filozoficznych bądź teologicznych, a niekiedy całych doktryn światopoglądowych lub politycznych, aksjologia pedagogiki dialogu odwołuje się do doświadczenia. Przeżycie tego doświadczenia może prowadzić do egzystencjalnego zakorzenienia podstawowych wartości, stanowiąc przesłankę wychowania aksjologicznego. Tak pozyskane wartości nie są bowiem czymś zapożyczonym, lecz dzięki doświadczeniu mogą zostać uwewnętrznione - egzystencjalnie przywłaszczone. W tym sensie aksjologia pedagogiki dialogu jawi się jako oryginalna propozycja, która uzasadnia normatywny charakter kształcenia bez konieczności prymarnego odwoływania się do zewnętrznych kodeksów etycznych. Aby tak się jednak stało, pedagogika dialogu powinna zostać odczytana nie tylko w kategoriach fenomenologicznych, lecz również hermeneutycznych.

\section{Aksjologiczna heteronomia współczesnej pedagogiki}

Podstawową i historycznie pierwotną egzemplifikacją kwestii aksjologicznych w szeroko pojętej edukacji jest tematyka celów kształcenia. Cele wiązano bowiem z urzeczywistnieniem określonych wartości. Innymi słowy, mimo iż cele opisywały różne osiągnięcia, np. umiejętności, czy też odwoływały się do faktycznej, a nie postulowanej teleologii życia, były ko- 
niec końców podporządkowane wartościom uznawanym za normatywne. Konstatując rozwój pedagogiki, można jednak zdiagnozować nową tendencję. Zanim to jednak uczynimy, należy podkreślić, że przedstawiona poniżej interpretacja jest z natury rzeczy bardzo ogólna, a co za tym idzie subiektywna, tym niemniej próbuje ukazać prawdopodobną logikę następstw. Wydaje się bowiem, że wraz z rozwojem empirycznie zorientowanych teorii curricularnych - teorii przebiegu procesu kształcenia, w tym taksonomii celów kształcenia i koncepcji pomiaru dydaktycznego, zaczęto wyrażać cele edukacyjne nie tyle w kategoriach wartości do urzeczywistnienia, ile umiejętności mentalnych i praktycznych. Podejście takie nie tylko „upraktyczniało" kształcenie, lecz również umożliwiało jego empiryczną operacjonalizację, kontrolę, standaryzację i ewaluację. Wyrazem tej tendencji było poszukiwanie nowych kategorii pedagogicznych, które miały uzupełnić bądź wręcz zastapić tradycyjne pojęcie celów kształcenia. W ten sposób istotnym elementem opisu procesu dydaktycznego stała się kategoria kompetencji, w tym kompetencji kluczowych. Zadaniem kształcenia stało się tym samym wyposażenie ucznia $\mathrm{w}$ odpowiednie kompetencje poznawcze, kulturowe, społeczne, zawodowe czy praktyczne. Pozyskanie owych kompetencji powinno tworzyć - na wzór teorii organizacji i zarządzania - swoisty zasób osobowy jednostki kształconej. Podejście takie zyskało wsparcie ze strony polityków oświatowych, którym tego typu terminologia w sposób szczególny przypadła do gustu. W sposób naturalny wpisywała się ona bowiem w rozumienie edukacji jako instrumentu rozwoju społeczeństwa wiedzy, nowoczesnych technologii i efektywnej gospodarki. Zamarkowaną tendencję wyrażały i jednocześnie dodatkowo wzmacniały badania osiagnięć edukacyjnych uczniów i efektywności systemów oświatowych, opierające się na empirycznej operacjonalizacji i standaryzacji kształcenia. W tym sensie miarą edukacji szkolnej stały się uzyskane przez uczniów wymierne kompetencje.

Prymat kształtowania kompetencji kosztem wychowania do wartości zapewne był także spotęgowany trudnościami związanymi z dydaktycznym transferem samych wartości oraz obawami dotyczącymi niebezpieczeństwa indoktrynacji. Tak więc niezamierzonym skutkiem tego procesu stał się spadek zainteresowania aksjologią. Oczywiście, powyższe nie oznacza wyrugowania problematyki aksjologicznej z kształcenia. Tyle tylko, że za miejsce jej stanowienia uznano preambuły aktów oświatowych, deklaracje i dokumenty programowe, postawy konkretnych nauczycieli, natomiast w mniejszym stopniu - dociekania pedagogiczne.

Opisana tutaj logika następstw nie jest bezzasadna. Tego typu tendencje zdiagnozowali również autorzy obszernego memorandum edukacyjnego Kościoła ewangelickiego w Niemczech Miara człowieczeństwa. Ewangelic- 
kie perspektywy dla kształcenia $w$ spoteczeństwie wiedzy i edukacji ${ }^{1}$. Ukazało się ono jako próba odpowiedzi na toczoną w Niemczech debatę pedagogiczną i społeczną, dotyczącą jakości kształcenia w kontekście wyników studiów PISA. Jego autorzy domagali się tego, aby miarą wiedzy stało się na powrót to, co stanowi o fundamentach człowieczeństwa. Poszerzanie wiedzy przyrodoznawczo-technicznej i rozwój konkretnych kompetencji są niewątpliwie jednym z ważniejszych czynników rozwoju nowoczesnej gospodarki. Jednak tego typu kształcenie nie oznacza automatycznie uzyskania orientacji w świecie. Memorandum kończy 20 tez, z których pierwsze głoszą:

1. [...] Kształcenie odnosi się do każdego człowieka z osobna jako osoby, jego wspierania i rozwoju jako 'całego człowieka' i jego wychowania do odpowiedzialności społecznej za wspólnotę. 2. Kształcenie odzwierciedla jako roszczenie kulturowe orientację danego społeczeństwa w zakresie sensów i wartości, i dlatego domaga się ciagłego publicznego dyskursu edukacyjnego. [...] 4. Kształcenie musi treściowo kwalifikować wiedzę i nauczanie. 'Wiedza' i 'nauczanie' są pojęciami funkcjonalnymi. Same w sobie nie zawierają kryteriów tego, czego powinno się nauczać2.

W tym sensie memorandum wskazuje na znaczenie rozstrzygnięć normatywnych - ontologicznych (antropologicznych) i aksjologicznych dla teorii i praktyki pedagogicznej. Rozstrzygnięcia te nie mają mieć jednak charakteru pozapedagogicznego, lecz mają wynikać z historycznego, estetycznego, religijnego, etycznego i filozoficznego pogłębienia pojęcia i procesu kształcenia.

Należy podkreślić, że naszkicowana tutaj tendencja do dystansowania się pedagogiki wobec aksjologii nie tyle mogła wynikać z lekceważenia aksjologii, ile o wiele bardziej z przekonania, że jako namysł normatywny w swoich podstawach wykracza ona poza refleksję pedagogiczną. Innymi słowy, stwierdzono, że aksjologia zachowuje znaczenie dla myślenia o wychowaniu, jednak jej źródła są pozapedagogiczne - etyczne, światopoglądowe, polityczne. Powyższe prowadzi do delegowania rozstrzygnięć aksjologicznych w kształceniu poza refleksję pedagogiczną - na decydentów oświatowych oraz konkretnych nauczycieli, a w konsekwencji na przyjmowane przez nich systemy aksjologiczne. Powyższa konstatacja nie ma formy zarzutu. Nie odnosi się ona również do oceny dokonanych wyborów aksjologicznych. Jej

${ }^{1}$ Maße des Menschlichen. Evangelische Perspektiven zur Bildung in der Wissens- und Lerngesellschaft. Eine Denkschrift des Rates der Evangelischen Kirche in Deutschland, Gütersloh 2003.

2 Tamże, s. 89-90. 
celem jest natomiast dostrzeżenie faktu, że przedstawiona powyżej logika zdarzeń sprawiła, że przesłanki przyjmowanej aksjologii oświatowej nie tyle są wynikiem rozstrzygnięć pedagogicznych, ile - powtórzmy - etycznych, światopoglądowych, politycznych. Powyższe grozi jednak niebezpieczeństwem aksjologicznej heteronomii - sytuacji, w której wartości są stanowione „zewnętrznymi” względem ucznia aktami, a nie sytuacją wychowawczą i związanym z nią doświadczeniem egzystencjalnym. Co więcej, w sytuacji, w której wychowanie ku wartościom nie jest pedagogicznie zdefiniowane, powstaje realne niebezpieczeństwo indoktrynacji - narzucania wartości, zamiast ich odkrywania.

W świetle powyższego zasadne wydaje się stwierdzenie, że aksjologia pedagogiczna nie powinna być automatyczną konsekwencją rozstrzygnięć normatywnych, dokonywanych z perspektywy dominującej w danym kraju tradycji bądź kultury. W o wiele większym stopniu powinna ona bowiem wyrastać z doświadczenia egzystencjalnego, opisanego pedagogicznie, związanego z procesem kształcenia, a dopiero w kolejnym etapie uwzględniać przyjmowany horyzont normatywny - orientację danego społeczeństwa w zakresie sensów i wartości jako formy roszczenia kulturowego i w konsekwencji edukacyjnego. Historia myśli pedagogicznej dostarcza wielu przykładów, że pedagogika była i jest w stanie formułować twierdzenia normatywne wywiedzione prymarnie $\mathrm{z}$ analizy rzeczywistości wychowawczej. Oryginalny wkład w tym zakresie dostarczyły m.in. pedagogika kultury jako pedagogika filozoficzna i humanistyczna, pedagogika pragmatyzmu i neopragmatyzmu czy pedagogika krytyczna. Każda z nich, wychodząc od swoistych rozstrzygnięć teoretycznych, opracowała katalog wartości i sensów jako ogólnych celów kształcenia, dla których kodeksy etyczne i światopogląd stanowiły horyzont, a nie podstawową przesłankę. Podobną intencję można wyprowadzić z filozofii i pedagogiki dialogu, co potwierdza znamienna wypowiedź M. Bubera:

Nie ma i nigdy nie było żadnej normy czy maksymy dla wychowania. To, co się zwykło tak nazywać, było li tylko normą jakiejś kultury, jakiegoś społeczeństwa, jakiegoś Kościoła, jakiejś epoki, której wychowanie, podobnie jak inne ruchy czy akty duchowe podporządkowywało się. [...] Wyłącznie w dezintegracji tradycyjnych więzów, w wirze wolności rodzi się odpowiedzialność osobowa, nie znajdująca więcej oparcia w żadnym Kościele, w żadnym społeczeństwie czy kulturze: samotna odpowiedzialność w obliczu bytu

${ }^{3}$ M. Buber, Wychowanie, w: Źródła do dziejów wychowania i myśli pedagogicznej, wybór i oprac. S. Wołoszyn, Kielce 1998, t. 3 księga 2, s. 655. 


\section{Aksjologia wychodząca od doświadczenia jako problem etyki}

Drogą do pedagogicznego zakorzenienia rozstrzygnięć aksjologicznych jest oparcie namysłu aksjologicznego i praktyki wychowania do wartości na doświadczeniu. Innymi słowy, wartości ważne pedagogicznie powinny być wyprowadzane nie tyle z zewnętrznych katalogów, ile z centrum egzystencji ludzkiej. Zawężając problematykę aksjologii jedynie do aspektu etycznego, można podać różne egemplifikacje tego typu prób podejmowanych na gruncie etyki.

W tym miejscu odwołamy się do jednostkowego przykładu takich dokonań, a mianowicie do propozycji etycznej sformułowanej przez Alberta Schweitzera. Jednym z ważniejszych problemów refleksji etycznej jest napięcie pomiędzy tzw. etyką zasad a tzw. etyką sytuacyjną. Etyka zasad, ujmując to w największym skrócie, jest pozycją w zakresie etyki normatywnej, która stara się ustalić bardziej szczegółowy kodeks postępowania w określonych sytuacjach - innymi słowy, to nie tyle sytuacja, ile przyjęte normy powinny wyznaczać postępowanie człowieka. Etyka sytuacyjna, często o orientacji egzystencjalnej, podkreśla natomiast niepowtarzalność każdej sytuacji i dokonywanych w jej kontekście wyborów. Opozycję pomiędzy tymi stanowiskami próbował pozytywnie rozwiązać m.in. wspomniany powyżej Schweitzer, lekarz, muzykolog, a zarazem filozof i teolog protestancki. W pracy Filozofia kultury, a zwłaszcza w jej części pt. Kultura a etyka, odrzucił iluzję autorytatywnego przekazu umiejętności wyboru pomiędzy tym, co jest dobre, a tym, co jest złe. Punktem wyjścia kształtowania wrażliwości etycznej, zdolności wartościowania i formułowania etycznego osądu powinien być nie tyle zewnętrzny katalog normatywny, ile doświadczenie egzystencjalne, fakt na poziomie świadomości ludzkiej. Poszukując podstawowej zasady postępowania pisał:

Prawdziwa filozofia musi wychodzić z najbardziej bezpośredniego i najdalej sięgającego faktu świadomości: Jestem życiem, które pragnie żyć, pośród życia, które pragnie żyć. [...] Etyka polega więc na tym, że przeżywam pragnienie okazywania równie głębokiej czci dla życia w stosunku do wszelkiej woli życia, jak w stosunku do własnej. Tym samym dana jest podstawowa zasada moralna, zasada myślowo konieczna. Utrzymywać życie i działać na korzyść życia - oto co jest dobre; niszczyć życie i ograniczać życie - oto co jest złe".

${ }^{4}$ A. Schweitzer, Filozofia kultury, w: I. Lazari-Pawłowska, Schweitzer, Warszawa 1976, s. $183-184$. 
Schweitzer tym samym wskazał na uniwersalną i podstawową zasadę (wartość) każdego wyboru etycznego, także w obszarze wychowania. Wspieranie rozwoju wychowanka, zarówno w wymiarze biologicznym, jak i duchowym - intelektualnym, emocjonalnym i aksjologicznym, budowanie tożsamości jednostkowej i wspólnotowej, solidarności grupowej jest dobrem. Przeciwstawienie się wspieraniu życia jest natomiast złem. Zasada (wartość) czci dla życia (i jej etyczne implikacje) ma walor bezwzględnego obowiązywania i jest egzystencjalnie uniwersalna. „Etyka czci dla życia nie uznaje etyki względnej. Jako dobre każe traktować tylko zachowanie i krzewienie życia. Wszelkie niszczenie i szkodzenie życiu, w jakichkolwiek okolicznościach by następowało, określa jako zło"s.

Schweitzer nie chciał jednak abstrahować od rzeczywistości i konkretnych sytuacji życiowych. Wręcz przeciwnie, według niego, etyka powinna prowadzić człowieka do konfrontacji z rzeczywistością. Etyka nie rozstrzyga konfliktów za człowieka, ale uświadamia mu fakt, że jest odpowiedzialny za to, w jakim stopniu pozostaje etyczny, w jakim natomiast poddaje się konieczności niszczenia bądź szkodzenia życiu, a tym samym obarcza się wina. W tym sensie uniwersalna etyka czci dla życia zostaje połączona z zasadąjednostkowej odpowiedzialności wobec wymogów konkretnych sytuacji i dokonywanych wyborów. Od tych wyborów, także „wbrew czci dla życia”, nie ma bowiem ucieczki, a tym samym nie ma ucieczki od poczucia winy. Paradoksalnie, poczucie winy stanowi o godności człowieka. Schweitzer pisał: „Nie wolno nam nigdy utracić wrażliwości. Żyjemy w prawdzie, jeśli coraz głębiej przeżywamy konflikty. Czyste sumienie jest wynalazkiem diabła". Pomijając konsekwencje i znaczenie etyki czci dla życia, można stwierdzić, że ukazuje ona możliwość formułowania aksjologii, także o charakterze pedagogicznym, która nie ma charakteru dogmatycznego i nie jest wyprowadzana z zewnętrznego wobec jednostki kanonu wartości. Jej źródłem staje się doświadczenie egzystencjalne - przeżywanie siebie jako istoty cechującej się wolą życia, a jednocześnie uwikłanej w konflikty wyborów etycznych.

\section{Pedagogika dialogu jako fenomenologia i hermeneutyka obecności}

Implikacjom pedagogicznym myślenia dialogicznego poświęconych zostało wiele prac, począwszy od klasyków filozofii dialogu? , a skończyw-

5 Tamże, s. 192.

${ }^{6}$ Tamże, s. 192.

7 M. Buber, Schriften zu Jugend, Erziehung und Bildung, Gütersloh 2005 (t. 8 w ramach edycji Martin Buber Werkausgabe). W przekładzie polskim ukazał się zaledwie jeden przyczynek pedagogiczny, a mianowicie uprzednio cytowany artykuł pt. Wychowanie = Rede über 
szy na tomie wydanym przez J. Rutkowiak ${ }^{8}$ czy ostatnich dokonaniach środowiska naukowego Akademii Pedagogiki Specjalnej w Warszawie ${ }^{9}$. Z tego też względu w niniejszym artykule pominiemy opis rudymentów filozofii i pedagogiki dialogu. Skoncentrujemy się natomiast na jednym aspekcie, a mianowicie na dialogicznych przesłankach aksjologii pedagogicznej.

Rozpocznijmy nasze dociekania od teoretycznej i metodologicznej konstatacji. Otóż filozofia i pedagogika dialogu są często odbierane w kategoriach fenomenologicznych. $\mathrm{Z}$ tej perspektywy proponują one swoistą fenomenologię obecności. Najogólniej rzecz ujmując, podejście fenomenologiczne dąży do opisania rzeczywistości, jak się jawi postrzegającemu ją podmiotowi, w horyzoncie jego doświadczenia, przed próbami jej interpretacji. Punktem wyjścia w takim podejściu staje się więc nie tyle przedmiotowa, ile podmiotowa strona poznania. Fenomenologia koncentruje się bowiem nie na przedmiocie samym w sobie, lecz na tym, w jaki sposób zjawia bądź uobecnia się on w postrzeganiu poznającego podmiotu. W tym sensie, jak to jest często podkreślane np. w tradycji niemieckiej, fenomenologia jest nauką, której przedmiotem jest podmiotowe postrzeganie rzeczywistości (Wahrnehmungswissenschaft).

Ujęcie takie powodowało częste rozdzielenie badań fenomenologicznych i hermeneutycznych. O ile domeną fenomenologii miał być opis rzeczywistości zjawiającej się w podmiotowym postrzeganiu, o tyle przedmiotem badań hermeneutycznych miało być rozumienie tejże. W odróżnieniu od fenomenologii hermeneutyka miała być bowiem sztuką interpretacji (ars interpretandi). Z dzisiejszej perspektywy takie rozróżnienie daje się obronić jedynie w odniesieniu do fenomenologii transcendentalnej, np. transcendentalnej i idealistycznej fenomenologii E. Husserla, poszukującej uprawomocnienia poznania na poziomie tzw. czystej świadomości. Jeżeli jednak odrzucimy wiarę Husserla, że jest możliwa analiza i konstruowanie aktów poznania o charakterze transcendentalnym, a więc poza poziomem świadomości człowieka, wtedy opis fenomenologiczny i rozumienie hermeneutyczne zaczynają się ze sobą splatać. Należy bowiem podkreślić, iż podważenie transcendentalizmu, a tym samym „uempirycznienie” opisów fenomenologicznych, jest podstawową przesłanką współczesnego ruchu fenomenologicznego, określającego siebie mianem nowej fenomenologii ${ }^{10}$.

das Erzieherische, w: tegoż, Schriften zu Jugend, s. 136-154; E. Lévinas, Trudna wolność. Eseje o judaizmie, Gdynia 1991, s. 283-309.

8 J. Rutkowiak (red.), Pytanie, dialog, wychowanie, Warszawa 1992.

${ }^{9}$ E. Dąbrowa, D. Jankowska (red.), Pedagogika dialogu. Dialog warunkiem rozwoju osobowego i społecznego, Warszawa 2008; J. Gara, Pedagogiczne implikacje filozofii dialogu, Kraków 2008.

${ }^{10}$ H. Schmitz, Nowa fenomenologia, Poznań 1995; Neue Phänomenologie, Bonn 1980. 
Skoro bowiem opis rzeczywistości dotyczy uobecniającego się świata w postrzeganiu, na poziomie świadomości, a więc systemu poznawczego jednostki i właściwych dla niej schematów i struktur poznawczych, to nie powinno się dłużej oddzielać opisu od rozumienia i interpretacji.

Po pierwsze, na nasze poznanie mają wpływ nie tyle czyste formy na poziomie transcendentalnej świadomości, ile uwarunkowania wynikające $\mathrm{z}$ naszego zakorzenienia $\mathrm{w}$ świecie życia codziennego. To właśnie one, co markował w późniejszym okresie swojej twórczości E. Husserl, a wyeksplikował A. Schütz, stanowią transcendentalną podstawę postrzegania rzeczywistości ${ }^{11}$. I po drugie, z perspektywy pedagogiki punktem odniesienia aksjologii powinna być nie tyle fenomenologia rzeczy czy fenomenologia transcendentalnych wartości, istniejących w świecie idei, ile fenomenologia podmiotowego postrzegania uwarunkowanego rzeczywistością społeczną rzeczywistością świata codziennego jako postacią interakcji symbolicznych. $\mathrm{W}$ takiej fenomenologii podstawową kategorią staje się nie tyle istota rzeczy, ile sens rzeczywistości ludzkiej. Kategoria sensu jest tym, co łączy podejście fenomenologiczne z hermeneutyka. Sens jest bowiem zasadą semantyczna, która sprawia, że daną rzeczywistość postrzegamy w kategoriach znaczącej całości. Z tego też względu H. Nohl konstatował: „Prawdziwym punktem wyjścia dla relewantnej teorii kształcenia jest fakt rzeczywistości wychowawczej jako sensownej całości"12.

Z tej perspektywy doświadczenie obecności, doświadczenie drugiej osoby, a za jej pośrednictwem - siebie samego, nie ma charakteru ahistorycznego czy aczasowego. Ono nie jest wydarzeniem chwili, w której uniwersalna i wieczna idea ujawnia się w rzeczywistości społecznej. Gdyby tak miało być, to metodą opisu takiego doświadczenia byłaby transcendentalna, idealistyczna fenomenologia. Doświadczenie obecności jest zawsze egzystencjalnie i społecznie konkretne i jest związane z ujawnianiem egzystencjalnego sensu, który pozwala postrzegać rzeczywistość jako znaczącą całość. Ja-Ty i Ja-Ono jako podstawowe kategorie pojęciowe filozofii dialogu, określające sposoby relacyjności bytu ludzkiego, są nośnikami egzystencjalnego sensu. Nie są więc jedynie narzędziem filozoficznego, teoretycznego opisywania rzeczywistości, ale swoistym medium znaczeń, które można wyinterpretować i rozumiejąco przywłaszczyć w trakcie relacji interpersonalnych. I właśnie dlatego, że nie mają one charakteru idealistycznego, lecz są rzeczywistością daną do rozumienia i interpretacji, wymagają kształcenia i wsparcia pedagogicznego.

${ }^{11}$ A. Schütz, Der sinnhafte Aufbau der sozialen Welt, Frankfurt am Mein 1991.

${ }^{12}$ H. Nohl, Die pädagogische Bewegung in Deutschland und ihre Theorie, Frankfurt am Main 2002, s. 150. 
Powyższe dociekania przekonują, że pedagogika dialogu może być nie tylko postrzegana w kategoriach fenomenologii, lecz również hermeneutyki obecności. Tym samym nie tylko dostarcza elementarnych opisów podstawowych fenomenów ludzkiej egzystencji - relacji dialogicznej i wydarzającego się w jej kontekście spotkania, lecz również identyfikuje i interpretuje konstytutywne dla tych wydarzeń sensy. $Z$ tego też względu stanowić może przesłankę aksjologii, i to nie tylko filozoficznej, lecz również pedagogicznej. Podstawową cechą tej aksjologii jest wyprowadzanie wartościowania i rozumienia rzeczywistości z elementarnego doświadczenia dialogu i spotkania.

\section{Dialogiczne przesłanki aksjologii pedagogicznej}

Dialog nie jest jedynie wymianą myśli, formą konwersacji czy komunikacji. Jego konieczną przesłanką jest podmiotowa obecność osób. Dialog opiera się bowiem na relacyjnej strukturze bytu ludzkiego i z tego względu jest formą uobecniania i spotkania. Pedagogiczne znaczenie dialogu musi więc bazować na rozpoznaniu sensu egzystencji ludzkiej w kategoriach obecności, podmiotowego sposobu bycia, które są przesłanką postrzegania i nawiązywania relacji społecznych. W dialogu nie odbieram drugiego jedynie przez pryzmat fizjonomii, estetyki ciała i ubioru czy profesjonalnych kompetencji, lecz z perspektywy jego obecności jako osoby. Doświadczenie obecności, co stanowi jedną z tez niniejszego opracowania, jest nierozerwalnie związane $\mathrm{z}$ rozumieniem tejże obecności. $\mathrm{Z}$ tej perspektywy pedagogika dialogu implikuje swoistą hermeneutykę doświadczenia obecności bądź prościej - hermeneutykę obecności. Doświadczenie obecności i jego hermeneutyka mogą z kolei stanowić przesłankę aksjologii pedagogicznej.

Podstawowym kluczem otwierających dostęp do rozumienia doświadczenia obecności jest spotkanie, które jest wydarzeniem tworzenia się przyjaźni między dialogującymi osobami będącej formą, jak to metaforycznie ujmował M. Buber, „obejmowania się” dwóch istot. Wydaje się jednak, że doświadczenie i leżące u jego podstaw rozumienie obecności jest o wiele bardziej kompleksowe. Według E. Lévinasa i J. Tischnera, istotną rolę odgrywa doświadczenie ludzkiej twarzy i wynikające z niego wezwanie etyczne. Drogą dostępu do rozumienia obecności jest także pojawiające się w dialogu odczucie powinowactwa duchowego osób czy też uświadomienie indywidualności osoby w imieniu i nazwisku. Całość tych elementów stanowi więc egzystencjalny klucz do rozumienia obecności i wynikającej stąd powinności etycznej. To właśnie dzięki tym doświadczeniom jednostka może zrozumieć obecność drugiego człowieka jako człowieka właśnie, jako 
podmiotu, a nie przedmiotu, jako Ty mającego swoje własne Ja. Aksjologia pedagogiki dialogu jest więc rozwinięciem swoistej tautologii: człowiek jest człowiekiem. Jej egzystencjalną przesłanką staje się dialogiczne doświadczenie obecności drugiego jako człowieka właśnie. W tym doświadczeniu zakorzenione są podstawowe wartości - niezbywalna godność i wolność osoby ludzkiej. Wartości te, co należy podkreślić, nie są przypisywane jedynie drugiej osobie, lecz dzięki takiemu jej postrzeganiu - zgodnie z podstawowym przekonaniem hermeneutyki o zapośredniczonym charakterze rozumienia - mogą stać się częścią tożsamości Ja. Kształtowanie wrażliwości na obecność drugiego człowieka jest zarazem umiejętnością rozumienia siebie w kategoriach podmiotu - nie jako sumy elementów, lecz jako całości bytu ludzkiego, któremu przysługują konkretne walory etyczne.

Powyższe myślenie ma jednak swojego konkurenta w postaci tendencji do uprzedmiotowienia rzeczywistości. Tendencja ta polega na przyjmowaniu w opisie świata kategorii mentalnych stosowanych do rzeczy i rozciąganiu ich na całą rzeczywistość. Tego typu sposób myślenia jest niewątpliwie warunkowany rozwojowo - jest charakterystyczny dla wczesnego etapu życia ludzkiego. Problem polega jednak na tym, że cechy takiego myślenia nie zanikają $\mathrm{w}$ sposób automatyczny wraz z osiagnięciem określonego wieku metrykalnego. Przezwyciężenie myślenia uprzedmiotowiającego w odniesieniu do relacji międzyludzkich jest zadaniem wychowania moralnego, a tym samym kwestią aksjologii pedagogicznej. Podstawowym punktem odniesienia dla takiego wychowania powinno być jego zakorzenienie w świecie sensów i wartości. Jednak owe sensy i wartości nie powinny być stanowione ani zewnętrznym wobec ucznia katalogiem etycznym, co prowadzi do - jak to nazwaliśmy - aksjologicznej heteronomii, ani być wynikiem ich uniwersalnego, ahistorycznego, ,apodyktycznego" i oczywistego ujawniania się (przedmiot opisu fenomenologii transcendentalnej). Innymi słowy, przezwyciężanie myślenia uprzedmiotowiającego dokonać się może przez uznanie prymarności postrzegania podmiotowego. Tyle tylko że sens i wartość podmiotowości nie jest dana w sposób absolutny, lecz ujawnia się w konkretnej, społecznej i egzystencjalnej sytuacji jako coś nieoczywistego, wymagającego interpretacji i rozumienia, a przez to związanego z wysiłkiem pedagogicznym. Tylko w medium konkretnych dialogów uczeń może nauczyć się traktować drugiego człowieka jako człowieka właśnie, jako podmiot obdarzony przymiotami etycznymi. Tylko poprzez konkretne doświadczenia może być realizowana dialogiczna idea uwrażliwienia na obecność drugiego człowieka w świecie.

Konkludując można stwierdzić, że z perspektywy pedagogiki dialogu można formułować cele kształcenia i wynikające $\mathrm{z}$ nich kompetencje edukacyjne, których główną ideą jest uwrażliwienie na obecność człowieka 
w świecie. Będą to jednak cele i kompetencje odzwierciedlające konkretną aksjologię zakorzenioną w doświadczeniu i rozumieniu dialogicznej obecności osób. W tym sensie pedagogika dialogu otwiera przed teorią wychowania możliwość samodzielnego formułowania celów i kompetencji opartych na aksjologii wyrastającej z doświadczenia. Aksjologia taka nie jest heteronomiczna, nie jest wypadkową jakiejkolwiek zewnętrznej normatywności, a zarazem umożliwia różnym tradycjom kulturowym rozpoznanie się w wartościach realizowanych $\mathrm{w}$ procesie dydaktycznym.

\section{Axiology of education in perspective of the pedagogy of dialogue (Summary)}

Standardisation is the feature of modern school education. Its result is a replacement of goals described in value categories with the goals expressed in the form of competences. This understanding may lead the pedagogy to the so called axiological heteronomy. The present article calls for the need of connection between the schools educational activity and pedagogical axiology. The sources of pedagogical axiology should not be rooted in the external codes of values or norms, but in the experience of educational reality. The meaning of the pedagogy of dialogue is presented from this perspective. The analysis of dialogical structure of human being describes the experience of presence of the other human not only in phenomenological, but also in hermeneutical categories - exposure of the meaning of ethical foundation of human being belongs to its essence. The dialogical 'hermeneutics of presence' can be understood as the existential reference point for formation of individual moral sensibility, ethical convictions and for pedagogical axiology. 
